\title{
UDC 628.16
}

\author{
S. M. EPOYAN ${ }^{1 *}$, V. A. YARKIN ${ }^{2}$, G. I. SUKHORUKOV ${ }^{3}$, S. P. BABENKO ${ }^{4}$ \\ ${ }^{1 *}$ Dep. «Water Supply, Sewerage and Hydraulics», Kharkiv National University of Civil Engineering and Architecture, \\ Sumska St., 40, Kharkiv, Ukraine, 61002, tel. +38 (057) 70038 34, e-mail vkg.knuca@ukr.net, ORCID 0000-0003-4551-1309 \\ ${ }^{2}$ Dep. «Water Supply, Sewerage and Hydraulics», Kharkiv National University of Civil Engineering and Architecture, \\ Sumska St., 40, Kharkiv, Ukraine, 61002, tel. +38 (057) 70038 34, e-mail vkg.knuca@ukr.net, ORCID 0000-0001-7844-6772 \\ ${ }^{3}$ Dep. «Water Supply, Sewerage and Hydraulics», Kharkiv National University of Civil Engineering and Architecture, \\ Sumska St., 40, Kharkiv, Ukraine, 61002, tel. +38 (057) 70038 34, e-mail vkg.knuca@ukr.net, ORCID 0000-0002-1740-3098 \\ ${ }^{4}$ Dep. «Water Supply, Sewerage and Hydraulics», Kharkiv National University of Civil Engineering and Architecture, \\ Sumska St., 40, Kharkiv, Ukraine, 61002, tel. +38 (057) 70038 34, e-mail vkg.knuca@ukr.net, ORCID 0000-0001-7918-1737
}

\section{CORRIDOR-TYPE BAFFLED MIXING BASIN WITH CROSS POROUS BARRIERS}

Purpose. The paper hightlights the increase in operational efficiency of corridor-type baffled mixing basin by installing of cross porous barriers made of gravel (or other materials) and epoxy resin, grade ED-20 (ED-16) with the hardener polyethylenepolyamine (PEPA), approved by Ukrainian Ministry of Health in systems of utility and drinking water supply. Methodology. The first stage of the experiments was performed on the model of the proposed mixer in scale 1:4 in order to determine the local resistance of the porous barrier, which is made of gravel with a size of 10-15 mm (average diameter $12.5 \mathrm{~mm}$ ) and thickness of $50 \mathrm{~mm}$. The local resistance of the barrier was measured using piezometers installed before and after the porous barrier. The velocity of water motion in the corridor of the mixer was determined depending on the water consumption, incoming on the mixer accordingly to the water meter and by the volumetric method. Findings. In accordance with researches when the water flows at a velocity of $0.1 \mathrm{~m} / \mathrm{s}$ in the corridor of the mixer, the head losses in the porous barrier is $17 \mathrm{~cm}(0.17 \mathrm{~m})$, and at a velocity of $0.2 \mathrm{~m} / \mathrm{s}-0.68 \mathrm{~m}$. The resistance coefficient $(\xi)$, which is equal to 333.2 for the investigated barrier, was determined experimentally. It allows determining the head losses in the porous barrier at other velocities of water motion. When the velocity of water motion in the corridors of the mixer is from 0.7 up to $0.5 \mathrm{~m} / \mathrm{s}$, head losses increase almost fourfold. The conducted researches allowed to develop a calculation methodology for corridor-type baffled mixing basin with porous polymer-concrete barriers. Originality. Authors developed and investigated the corridor-type baffled mixing basin with porous polymer-concrete barriers. These barriers allow increasing and regulating the intensity and time of reagents mixing with the initial water exactly in the barriers, improving the distribution of the flow through the section of the mixer corridors. Practical value. The location of removable porous barriers in the corridors of the baffled mixing basin makes it possible to increase the efficiency of its operation and improve the quality of the treated water.

Keywords: baffled mixing basin; cross barriers; porous polymer-concrete; intensity of mixing; increase in operational efficiency

\section{Introduction}

One of the main users of drinking water are railways, therefore efficiency improvement of natural water purification is an urgent problem.

Coagulation is a powerful tool of intensifying the main process of natural waters purification, the successful completion of which results in the quality of the treated water supplied to the consumer $[4-6,14,20]$.

Intensification of the coagulation process is of great importance in connection with the increasing requirements for the quality of drinking water.

Through a rational process: the right choice of coagulants, flocculants, places and conditions for their introduction into water under purification, it is possible in many cases to increase the productivity of structures, to make a cheaper process and improve the quality of water purification [1, 10, 12, 13, 18].

In all cases, with the use of any coagulants, the conditions for mixing the reagent with water and the conditions for the flocculation are crucial for the further process of water clarification.

According to researchers, conducting the processes of mixing water with the coagulant and flocculation in optimal conditions leads to significant savings of the coagulant (up to 30\%), reduces the time of water presence in sediment basins due to the formation of quick-settling flocs, reduces the load on the filters on contamination (up 
to $50 \%$ ), increases the filter cycle and improves the quality of water purification $[3,7,9,17,19]$.

In most cases, when the coagulants are injected into the water, physical and chemical reactions occur, the ending of which until the time of full mixing of the reagent with water can lead to a violation of optimal coagulation conditions or to the excess coagulant. Thus, it is necessary to provide such a mode of operation of the mixers, so that the coagulant comes in contact with the maximum number of particles of contamination before the end of the of hydrolysis-polymerization reaction.

\section{Purpose}

The purpose of the study is increase in operational efficiency of corridor-type baffled mixing basin by installing of cross porous barriers made of gravel (or other materials) and epoxy resin, grade ED-20 (ED-16) with the hardener polyethylenepolyamine (PEPA), approved by Ukrainian Ministry of Health in systems of utility and drinking water supply. The first stage of the research: the experiments to determine the local resistance of the porous barrier.

On the basis of the conducted researches to develop a calculation method for corridor-type baffled mixing basin with porous polymer-concrete barriers.

\section{Methodology}

In solving the problems associated with water purification, the case of disperse systems coagulation dispersed in a moving fluid is considered. Disperse particles undergo Brownian motion, the intensity of which depends on the size of particles. In the process of aggregation caused by the Brownian motion, the colloidal particles reach the size at which the effect of the Brownian motion is stopped. If the further contact between the particles is not provided by mixing the water, coagulation is stopped. Sometimes this further contact is provided by the settling of the largest particles, which, while their moving downward capture smaller particles. The first phase of coagulation described above is called perikinetic one. Increasing the efficiency of perikinetic coagulation is achieved by reducing the stability of colloidal particles. Therefore, the phase of perikinetic coagulation stipulates the choice of type doi: $10.15802 / \operatorname{stp} 2018 / 124428$ and dose of coagulant. The phase of perikinetic coagulation ends when the particles reach a size of 1-10 microns. The phase of perikinetic coagulation coincides with the period of "rapid" mixing of coagulant with water, which significantly effects the efficiency of coagulating water purification.

Until recently, it was believed that the purpose of the mixers was to evenly distribute the coagulant in the water under purification. In domestic practice it is generally accepted that mixing should finish before the formation of flocs in the whole mass of water.

At present it is belived that mixing the coagulant with water should be carried out extremely fast and the process taking place in the mixer is crucial for furhther coagulation stages.

The direction of water purification technology associated with the instantaneous distribution of the coagulant in water is based on the coagulation theory, according to which the role of intermediate dissolved aluminum complexes in the destabilization of suspended particles is very great. At the same time, the required mixing velocity of the coagulant with water is dependent on the rate of formation of compounds capable to destabilize contaminant particles. Ineffective mixing can lead to the excess coagulant and a small rate of aggregation of particles at a given dose of coagulant $[5,10,12]$.

In our country the hydraulic mixers are widely used, including a corridor-type baffled mixing ba$\sin [5,6,10,13]$. The operation of mixers is accepted to characterize as the value of the average gradient of velocity $(\mathrm{G})$, that is, the intensity of mixing. Researches of Rozhdyestvyenska E. A., Mirzayev A. showed that the effectiveness of the coagulants and flocculants action increases with an increase in the intensity of mixing in comparison with the usual accepted one approximately $\mathrm{G}=250 \ldots 300 \mathrm{~s}-$. At the same time, the dose of reagents and the time required for their full distribution in water decreases with an increase in the velocity of the gradient [12].

The disadvantages of the corridor-type baffled mixing basin include: impossibility of regulating the intensity of mixing, the usage for mixing of only one reagent, the inadequate efficiency of its operation.

The Department of Water Supply, Sewage and Hydraulics at KHNUCA proposed and studied the

(C) S. M. Epoyan, V. A. Yarkin, G. I. Sukhorukov, S. P. Babenko, 2018 
corridor-type baffled mixing basin with slit-type cross barriers [16].

The disadvantages of the proposed baffled mixing basin are that the slit-type barriers located in the mixer channels only change the velocity of the water, owing to the mixing intensity increases. But mixing the reagents with the initial water does not occur particularly in the slit-type barriers.

Therefore, it is proposed to increase and adjust the intensity and time of mixing the reagents with the initial water in the barriers themselves and to improve the distribution of the flow through the section of the mixer corridors.

The problem is solved due to the fact that in the channels of the barrier mixer the removable porous barriers locate perpendicular to the barriers, which are made on the basis of a bonding agent $[11,15]$ (for example, porous polymer-concrete barriers). Porous barriers increase the intensity of mixing the reagents with the initial water due to the fact that mixing occurs not only in the volume of the mixer, but also in the porous barrier itself. Porous channels have a twisted shape that connect and separate the pore channels between themselves. The flows of the initial water and solutions of reagents that move along the pore channels collide with each other, connect and separate, which increases the intensity of mixing the reagents with the initial water. And the even flow of the initial water, mixed with the reagent, from the pore channels of the porous barrier improves the flow distribution along the corridor cross-section in the mixer. Changing the thickness of the porous barrier allows you to adjust the time of mixing of the initial water with the reagents in the porous barrier itself. Changing the filler material of the porous barrier allows to vary its porosity (for example, the porosity of shungizite $\approx 65 \%$ and volcanic slag $\approx 55 \%$ ), which makes it possible to change the flow velocity in the pore channels of the barrier, that is, to regulate the intensity of mixing in the barrier. Changing the particles sizes of the filler of the porous barrier changes the sizes of the pore channels of the barrier. The larger the size of the filler particles, the greater the size of the pore channels, which makes it possible to match the size of the filler particles for each reagent.

Porous barriers have local resistances, so they have to be set at the beginning or at the end of the channel in which they are located, since the water level before the porous barrier is greater than after it, and the velocity of water motion in the mixer channel have to meet current standards.

The proposed construction of an advanced corridor-type baffled mixing basin with porous barriers is schematically presented in Figure 1.

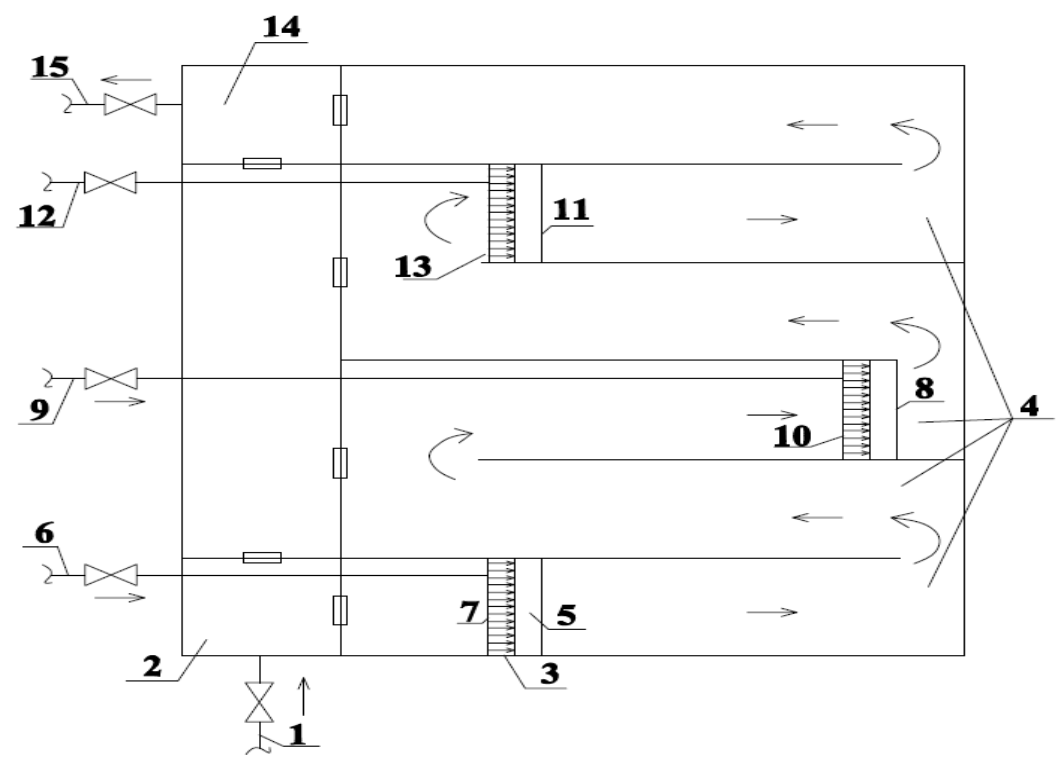

Fig. 1. Scheme of advanced corridor-type baffled mixing basin with porous barriers

The advanced baffled mixing basin consists of a pipeline of initial water supply -1 , a feed well -2 , body of an advanced baffled mixing basin -3 , channels of advanced baffled mixing basin -4 , porous barrier -5 , with the first type of the filler material and the size of its particles, as 
well as with the first thickness, the pipeline (hose) of the first reagent supply -6 , the dispersed tubular slit-type or perforated (holed) supply system of the first reagent (for example, chlorine reagent) -7 , porous barrier -8 , with the second type of the filler material and the size of its particles, as well as with the second thickness, the pipeline (hose) of the second reagent supply - 9, the dispersed tubular slit-type or perforated (holed) supply system of the second reagent (for example, coagulant) -10 , the porous barrier -11 , with the third type of the filler material and the size of its particles, as well as with the third thickness, the pipeline (hose) of the third reagent supply -12 , the dispersed tubular slit-type or perforated (holed) supply system of the third reagent (for example, the flocculant) -13 , the collection chamber -14 , pipeline -15 of the initial water diversion, mixed with reagents.

The advanced corridor-type baffled mixing basin with porous barriers operates in the following manner. The initial water through the pipeline -1 enters to the feed well -2 and then into the body of the advanced baffled mixing basin -3 in its first channel -4 , passing through the dispersed tubular slit-type or perforated (holed) supply system of the first reagent -7 , in which through the pipeline (hose) -6 the first reagent is fed and the porous barrier -5 , in which it is intensively mixed with the first reagent. Further, the mixing process and the contact time of the reagent with the initial water occur in channels -4 of the advanced baffled mixing basin. Then the initial water, which is mixed with the first reagent, enters the next channel 4 of the advanced baffled mixing basin, passes through the dispersed tubular slit-type or perforated (holed) supply system of the second reagent -10 , in which through the pipeline (hose) -9 the second reagent is fed and a porous barrier 8 , in which it is intensively mixed with the first and second reagents. Next, the mixing process and the contact time of the reagents with the initial water occur in channels 4 of the advanced baffled mixing basin. Then the initial water, which is mixed with two reagents, enters the next channel 4 of the advanced baffled mixing basin, passes through the dispersed tubular slit-type or perforated (holed) supply system of the third reagent -13 , in which through the pipeline (hose) -12 the third reagent is fed and the porous barrier -11 , in it it is intensively mixed with the third and the previous reagents. Further, the water, mixed with reagents, moves to last channels 4 of the advanced baffled mixing basin, enters the collecting chamber -14 and through the pipeline -15 is discharged from the mixer.

To verify the proposed solution to increase the efficiency of advanced baffled mixing basin due to the installation of transverse porous barriers in the mixer corridors, experiments were carried out on the model of such a mixer.

The first stage of experiments was carried out on the model of the proposed mixer 1:4 in order to determine the local resistance of the porous barrier.

The porous barrier is made of gravel, size $10 \div 15 \mathrm{~mm}$ diameter (average diameter $12.5 \mathrm{~mm}$ ) and epoxy resin, grade ED-20 with a polyethylenepolyamine (PEPA). This material is characterized by high strength, high chemical resistance to the aggressive effect of water treated with reagents, lack of biofouling in the course of long-term exploitation [2, 8]. The barrier has a thickness of $50 \mathrm{~mm}$. The local resistance of such a barrier was measured using the piezometers installed before and after the porous barrier. The velocity of water motion in the mixer corridor was determined depending on the duty of water supplied to the mixer, by the water meter and the volume method.

As it known, any local resistance can be determined by the formula [12]:

$$
h=\xi \frac{v^{2}}{2 g},
$$

where $\xi$ - coefficient of resistance; $v$ - velocity of water motion in the mixer; $g$ - free fall acceleration, equal to $9.8 \mathrm{~m} / \mathrm{s}^{2}$.

In this case, there is a question: how to define the velocity of motion $(v)$ if a porous barrier is installed. In other words, how to define the velocity of water motion exactly in the porous barrier. It can be realized, if we determine the porosity of this barrier (using the Archimedean method), and then recalculate the velocity of water motion exactly in the barrier pores. In our opinion, it is better to start out from the water motion velocity in the mixer corridors, it is an indirect approach to determining the velocity of water motion in the barrier pores, but directly depends on it. 
Thus, knowing the water level difference in front and behind the porous barrier (accordingly to the piezometer), knowing the velocity of water in this mixer corridor, where the porous barrier is installed, one can determine the resistance coefficient $(\xi)$ for the given porous barrier.

The research was carried out at the velocity of water motion in the mixer corridor from 0.1 up to $0.2 \mathrm{~m} / \mathrm{s}$.

Studies have shown that when the flow of water in the mixer corridor with velocity was about $0.1 \mathrm{~m} / \mathrm{s}$, the head losses in the barrier under research was $17 \mathrm{~cm}(0.17 \mathrm{~m})$, and at the velocity of $0.2 \mathrm{~m} / \mathrm{s}-0.68 \mathrm{~m}$.

Substituting the obtained experimental values in the formulas (1), we determine the resistance coefficient $\xi$. The resistance coefficient is 333.2. At the velocity of water motion in the mixer corridors from 0.7 to $0.5 \mathrm{~m} / \mathrm{s}$ [12] the head losses is from 8.33 to $4.25 \mathrm{~m}$ respectively. Such losses are relatively great. Therefore, it is recommended to arrange the pressure mode of motion in the mixer corridors before the porous barrier along the water motion, as well as to increase the size of the aggregate grains.

Baffled mixing basins are designed in the form of channels with barriers that provide a horizontal or vertical motion of water with 180-degree turn. Head loss on one turn is determined by the formula:

$$
h=\xi \frac{v^{2}}{2 g}
$$

where $\xi$-resistance coefficient, which is $2.9 ; v-$ velocity of water motion in the mixer corridor, which is from 0.7 to $0.5 \mathrm{~m} / \mathrm{s}$.

The velocity of water in each mixer corridor can be found by the formula:

$$
V_{i}=V_{i-1}-\left(V_{\text {str }}-V_{\text {end }}\right) / \mathrm{n},
$$

where $\mathrm{V}_{\mathrm{i}-1}$ - velocity of water motion in the previous corridor of the mixer, $\mathrm{m} / \mathrm{s} ; \mathrm{V}_{\mathrm{str}}$ - velocity of water motion in the first corridor of the mixer, which is taken $0.7 \mathrm{~m} / \mathrm{s} ; \mathrm{V}_{\text {end }}$ - velocity of water motion in the last corridor of the mixer, which is taken $0.5 \mathrm{~m} / \mathrm{s} ; \mathrm{n}$ - number of barriers.

Water depth in each corridor can be found by the formula:

$$
H_{i}=H_{i-1}-h-h_{n},
$$

where $\mathrm{H}_{\mathrm{i}-1}$ - depth of water in the previous mixer corridor, $\mathrm{m}$; $\mathrm{h}$ - head loss on the flow rotation, which are defined by the formula (2); $h_{n}-$ head loss in the porous barrier.

The width of each corridor is determined by the formula:

$$
B_{i}=q_{\text {mix }} /\left(V_{i} \cdot H_{i}\right)
$$

where $\mathrm{q}_{\text {mix }}$ - mixer performance, $\mathrm{m}^{3} / \mathrm{s} ; \mathrm{V}_{\mathrm{i}}$ - velocity of water motion in the corridor, $\mathrm{m} / \mathrm{s} ; \mathrm{H}_{\mathrm{i}}$ - water depth in the corridor, $\mathrm{m}$.

The construction length of the mixer is:

$$
L=\sum B_{i}+2 \delta_{\text {wall }}+\mathrm{n} \delta_{\text {bar }}
$$

where $\sum \mathrm{B}_{\mathrm{i}}-$ total width of all corridors, $\mathrm{m} ; \delta_{\text {wall }} \mathrm{i}$ $\delta_{\text {bar }}$-thickness of the mixer wall and the barrier between corridors respectively, $\mathrm{m}$.

Total mixer volume:

$$
W_{\text {mix }}=60 q_{\text {mix }} t
$$

where $\mathrm{t}$ - time of water presence in the mixer, which takes no more than 2 minutes.

The area of the mixer, coming from the depth of the first corridor will be:

$$
\omega=W_{\text {mix }} / H_{1},
$$

Based on the mixer volume and the total width of the corridors, we find the width of the mixer

$$
A=\omega / \sum B_{i},
$$

The head losses in each porous barrier are determined by the formula:

$$
h_{n}=\xi \frac{v_{c}^{2}}{2 g}
$$

where $v_{\mathrm{c}}$ - velocity of water motion in the corridor of the mixer, where a porous barrier is installed; $\xi$ - the resistance coefficient, which is determined experimentally for each porous barrier.

The total head losses are:

$$
\sum h=n \cdot h+h_{n} \cdot n_{1},
$$

where $n_{1}-$ number of porous barriers.

The thickness of the porous barrier must be not less than $50 \mathrm{~mm}$, and the size of the filler is not less than $30 \mathrm{~mm}$, which depends on the technological processes of mixing. Porous barriers 
are mounted in blocks no higher than $250 \mathrm{~mm}$ and up to $1000 \mathrm{~mm}$ in length.

\section{Findings}

Studies have shown that when the water flows in the mixer corridor at a velocity of $0.1 \mathrm{~m} / \mathrm{s}$, the head losses in the porous barrier was $17 \mathrm{~cm}(0.17$ $\mathrm{m}$ ), and at a velocity of $0.2 \mathrm{~m} / \mathrm{s}-0.68 \mathrm{~m}$. Accordingly to the obtained experimental values the resistance coefficient was determined $(\xi)$, which is 333.2 for the investigated barrier, which makes it possible to define the head losses in the barrier including other velocities of the water.

\section{Originality and practical value}

The corridor-type baffled mixing basin with porous polymer-concrete barriers was developed and investigated, which allows increasing and regulating the intensity and time of reagent mixing with the initial water exactly in the barriers and improving the distribution of the flow through the section of the mixer corridors.
Location of removable porous barriers in the corridors of the baffled mixing basin allows to increase its performance, and improve the quality of treated water.

\section{Conclusions}

The proposed construction of an advanced corridor-type baffled mixing basin with porous polymer-concrete barriers allows to increase and regulate the intensity and time of reagent mixing with the initial water exactly in the barriers and to improve the distribution of the flow through the section of the mixer corridors. It makes possible to change timely the technological processes of mixing the reagents with the initial water, depending on the physical-chemical indicators of the initial water, types and kinds of reagents that can be used at the water purification station.

Based on the conducted experiments, it is recommended to arrange the flow pressure mode in the mixer corridors before the porous barrier according to water flow, as well as to increase the size of the aggregate grains.

\section{LIST OF REFERENCE LINKS}

1. Водопостачання та очистка природних вод : навч. посіб. / С. М. Епоян, В. Д. Колотило, О. Г. Друшляк [та ін.]. - Харків : Фактор, 2010. - 192 с.

2. Выровой, В. Н. Особенности структурообразования и формирования свойств полимерных композиционных материалов / В. Н. Выровой, И. В. Довгань, С. В. Семенова. - Одесса : ТЭС, 2004. - 168 c.

3. Герасимов, Г. Н. Процессы коагуляуции-флокуляции при обработке поверхностных вод / Г. Н. Герасимов // Водоснабжение и санитарная техника. - 2001. - № 3. - С. 26-31.

4. Драгинский, В. Л. Коагуляция в технологии очистки природних вод / В. Л. Драгинский, Л. П. Алексеева, С. В. Гетманцев. - Москва : Наука, 2005. - 576 с.

5. Журба, М. Г. Водоснабжение. Проектирование систем и сооружений : учеб. пособие : в 3 т. / М. Г. Журба, Л. И. Соколов, Ж. М. Говорова. - 3-е изд., перераб. и доп. - Москва : АСВ, 2010. - Т. 2 : Очистка и кондиционирование природных вод. -532 с.

6. Запольский, А. К. Водопостачання, водовідведення та якість води : підручник / А. К. Запольский. Київ : Вища шк., 2005. - 671 с.

7. Мякишев, В. А. Модернизация коммунальных систем водоснабжения и водооотведения / В. А. Мякишев. - Симферополь : НАПКС, 2005. - 200 с.

8. Олейник, О. Ю. Использование полимербетона для строительства смотровых шахт систем водоотведения / О. Ю. Олейник, В. Ю. Кайдалов // Комунальне господарство міст : наук.-техн. зб. / Харк. нац. ун-т міськ. госп-ва ім. О. М. Бекетова. - Харків, 2014. - Вип. 114. - С. 18-21.

9. Повышение эффективности работы сооружений при очистке питьевой воды : монография / С. М. Эпоян, Г. И. Благодарная, С. С. Душкин, В. А. Сташук ; Харьк. нац. акад. гор. хоз-ва. - Харьков : ХНАГХ, 2013. - $190 \mathrm{c}$.

10. Реконструкція i інтенсифікація споруд водопостачання та водовідведення : навч. посіб. / О. А. Василенко, П. О. Грабовський, Г. М. Ларкіна [та ін.]. - Київ : Укргеліотех, 2010. - 272 с.

11. Рыбьев, И. А. Строительное материаловедение : учеб. пособие для вузов / И. А. Рыбьев. - Москва : Высш. шк., 2002. - 701 с. 


\section{ЕКОЛОГІЯ НА ТРАНСПОРТІ}

12. Теоретические основы очистки воды : учеб. пособие / Н. И. Куликов, А. Я. Найманов, Н. П. Омельченко, В. Н. Чернышев. - Донецк : Ноулидж (Донец. отд-ние), 2009. - 298 с.

13. Тугай, А. М. Водопостачання : підручник / А. М. Тугай, В. О. Орлов. - Київ : Знання, 2009. - 735 с.

14. Хоружий, П. Д. Ресурсозберігаючі технології водопостачання / П. Д. Хоружий, Т. П. Хомутецька, В. П. Хоружий. - Київ : Аграрна наука, 2008. - 534 с.

15. Шевченко, В. А. Технология и применение специальных бетонов : учеб. пособие / В. А. Шевченко. Красноярск : СФУ, 2012. - 201 с.

16. Эпоян, С. М. Метод повышения эффективности смешения природной воды и методика проведения исследований / С. М. Эпоян, Г. И. Сухоруков, В. А. Яркин // Наук. вісн. буд-ва : зб. наук. пр. / Харк. нац. техн. ун-т буд-ва та архітектури. - Харків, 2016. - № 1 (83). - С. 187-193.

17. Biliaiev, M. M. Numerical determination of horizontal settlers performance / M. M. Biliaiev, V. A. Kozachyna // Наука та прогрес транспорту. - 2015. - № 4 (58). - C. 34-43. doi: $10.15802 /$ stp2015/49201.

18. Bratby, J. Coagulation and Floculation in Water and Wastewater Treatment / John Bratby. - 3rd ed. - London : IWA Publishing, 2016. - 538 p. doi: 10.2166/9781780407500.

19. Kozachyna, V. A. Investigation of admixture sedimentation in the horizontal settler / V. A. Kozachyna // Наука та прогрес транспорту. - 2016. - № 4 (64). - С. 7-14. doi: 10.15802/stp2016/77827.

20. Pontius, F. W. Chitosan as a Drinking Water Treatment Coagulant / F. W. Pontius // American Journal of Civil Engineering. - 2016. - Vol. 4. - Iss. 5. - P. 205-215. doi: 10.11648/j.ajce.20160405.11.

\section{С. М. ЕПОЯН ${ }^{1 *}$, В. А. ЯРКІН ${ }^{2}$, Г. І. СУХОРУКОВ ${ }^{3}$, С. П. БАБЕНКО}

\footnotetext{
1*Каф. «Водопостачання, каналізація і гідравліка», Харківський національний університет будівництва та архітектури, вул. Сумська, 40, Харків, Україна, 61002, тел. +38 (057) 70038 34, ел. пошта vkg.knuca@ukr.net, ORCID 0000-0003-4551-1309

${ }^{2}$ Каф. «Водопостачання, каналізація і гідравліка», Харківський національний університет будівництва та архітектури, вул. Сумська, 40, Харків, Україна, 61002, тел. +38 (057) 70038 34, ел. пошта vkg.knuca@ukr.net,

ORCID 0000-0001-7844-6772

${ }^{3}$ Каф. «Водопостачання, каналізація і гідравліка», Харківський національний університет будівництва та архітектури, вул. Сумська, 40, Харків, Україна, 61002, тел. +38 (057) 70038 34, ел. пошта vkg.knuca@ukr.net, ORCID 0000-0002-1740-3098

${ }^{4}$ Каф. «Водопостачання, каналізація і гідравліка», Харківський національний університет будівництва та архітектури, вул. Сумська, 40, Харків, Україна, 61002, тел. +38 (057) 70038 34, ел. пошта vkg.knuca@ukr.net,

ORCID 0000-0001-7918-1737
}

\section{ПЕРЕГОРОДЧАСТИЙ ЗМШШУВАЧ КОРИДОРНОГО ТИПУ 3 ПОПЕРЕЧНИМИ ПОРИСТИМИ ПЕРЕГОРОДКАМИ}

Мета. У роботі необхідно розглянути підвищення ефективності роботи перегородчастого змішувача коридорного типу за рахунок встановлення поперечних пористих перегородок у коридорах змішувача, виконаних із гравію (або з інших матеріалів) та епоксидної смоли марки ЕД-20 (ЕД-16) із затверджувачем поліетиленполіаміном (ПЕПА), дозволеними Міністерством охорони здоров'я України в системах господарськопитного водопостачання. Методика. Перший етап експериментів проведений на моделі запропонованого змішувача у масштабі 1:4 для визначення місцевого опору пористої перегородки, яка виконана 3 гравію крупністю 10 $\div 15$ мм (середній діаметр 12,5 мм) і товщиною 50 мм. Місцевий опір перегородки вимірювався за допомогою п'єзометрів, встановлених перед і після пористої перегородки; швидкість руху води в коридорі змішувача визначалася в залежності від витрати води, що надходила на змішувач по лічильнику води, та об'ємним методом. Результати. Дослідження показали, що при русі потоку води в коридорі змішувача зі швидкістю 0,1 м/с втрати напору в пористій перегородці склали 17 см (0,17 м), а при швидкості 0,2 м/с0,68 м. За отриманими експериментальними значеннями був визначений коефіцієнт опору ( $\xi$ ), який дорівнює 333,2 для дослідженої перегородки, що дає можливість визначити втрати напору в перегородці й при інших швидкостях руху води. При швидкості руху води в коридорах змішувача від 0,7 до 0,5 м/с втрати напору збільшуються майже в чотири рази. На основі проведених досліджень розроблена методика розрахунку перегородчастого змішувача коридорного типу з пористими полімербетонними перегородками. Наукова новизна. Розроблено та досліджено перегородчастий змішувач коридорного типу з пористими полімербетонними перегородками, які дозволяють підвищити й регулювати інтенсивність і час змішування 
реагентів із вихідною водою в самих перегородках, поліпшити розподіл потоку по перерізу коридорів змішувача. Практична значимість. Розташування знімних пористих перегородок у коридорах перегородчастого змішувача дозволяє підвищити ефективність його роботи та поліпшити якість води, що очищується.

Ключові слова: перегородчастий змішувач; поперечні перегородки; пористий полімербетон; інтенсивність змішування; підвищення ефективності роботи

\section{С. М. ЭПОЯН ${ }^{1 *}$, В. А. ЯРКИН ${ }^{2}$, Г. И. СУХОРУКОВ ${ }^{3}$, С. П. БАБЕНКО ${ }^{4}$}

\footnotetext{
${ }^{1 *}$ Каф. «Водоснабжение, канализация и гидравлика», Харьковский национальный университет строительства и архитектуры, ул. Сумская, 40, Харьков, Украина, 61002, тел. +38 (057) 70038 34, эл. почта vkg.knuca@ukr.net, ORCID 0000-0003-1551-1309

${ }^{2}$ Каф. «Водоснабжение, канализация и гидравлика», Харьковский национальный университет строительства и архитектуры, ул. Сумская, 40, Харьков, Украина, 61002, тел. +38 (057) 70038 34, эл. почта vkg.knuca@ukr.net, ORCID 0000-0001-7844-6772

${ }^{3}$ Каф. «Водоснабжение, канализация и гидравлика», Харьковский национальный университет строительства и архитектуры, ул. Сумская, 40, Харьков, Украина, 61002, тел. +38 (057) 70038 34, эл. почта vkg.knuca@ukr.net, ORCID 0000-0002-1740-3098

${ }^{4}$ Каф. «Водоснабжение, канализация и гидравлика», Харьковский национальный университет строительства и архитектуры, ул. Сумская, 40, Харьков, Украина, 61002, тел. +38 (057) 70038 34, эл. почта vkg.knuca@ukr.net, ORCID 0000-0001-7918-1737
}

\section{ПЕРЕГОРОДЧАТЫЙ СМЕСИТЕЛЬ КОРИДОРНОГО ТИПА С ПОПЕРЕЧНЫМИ ПОРИСТЫМИ ПЕРЕГОРОДКАМИ}

Цель. В работе необходимо рассмотреть повышение эффективности работы перегородчатого смесителя коридорного типа за счет установки поперечных пористых перегородок в коридорах смесителя, выполненных из гравия (или других материалов) и эпоксидной смолы марки ЭД-20 (ЭД-16) с затвердителем полиэтиленполиамином (ПЕПА), разрешенными Министерством здравоохранения Украины в системах хозяйственно-питьевого водоснабжения. Методика. Первый этап экспериментов проведен на модели предложенного смесителя в масштабе 1:4 для определения местного сопротивления пористой перегородки, которая выполнена из гравия крупностью 10 $\div 15$ мм (средний диаметр 12,5 мм) и толщиной 50 мм. Местное сопротивление перегородки измерялось с помощью пьезометров, установленных перед и после пористой перегородки, скорость движения воды в коридоре смесителя определялась в зависимости от расхода воды, поступающей на смеситель по счетчику воды, и объемным методом. Результаты. Исследования показали, что при движении потока воды в коридоре смесителя со скоростью $0,1 \mathrm{~m} / \mathrm{c}$ потери напора в пористой перегородке составили 17 см (0,17 м), а при скорости 0,2 м/с - 0,68 м. Из полученных экспериментальных значений был определен

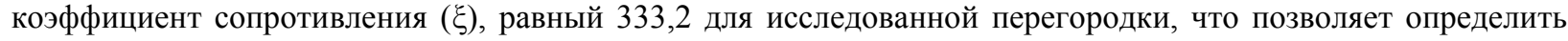
потери напора в перегородке и при других скоростях движения воды. При скорости движения воды в коридорах смесителя от 0,7 до 0,5 м/с потери напора увеличиваются почти в четыре раза. На основе проведенных исследований разработана методика расчета перегородчатого смесителя коридорного типа с пористыми полимербетонными перегородками. Научная новизна. Разработан и исследован перегордчатый смеситель коридорного типа с пористыми полимербетонными перегородками, которые позволяют повысить и регулировать интенсивность и время смешения реагентов с исходной водой в самих перегородках и улучшить распределение потока по сечению коридоров смесителя. Практическая значимость. Расположение съемных пористых перегородок в коридорах перегородчатого смесителя позволяет повысить эффективность его работы и улучшить качество очищаемой воды.

Ключевые слова: перегородчатый смеситель; поперечные перегородки; пористый полимербетон; интенсивность смешивания; повышение эффективности работы

\section{REFERENCES}

1. Epoyan, S. M., Kolotylo, V. D., \& Drushliak, O. H. (2010). Vodopostachannia ta ochystka pryrodnykh vod: Navchalnyi posibnyk. Kharkiv: Faktor. (in Ukrainian)

2. Vyrovoy, V. N., Dovgan, I. V., \& Semenova, S. V. (2004). Osobennosti strukturoobrazovaniya i formirovaniya svoystv polimernykh kompozitsionnykh materialov. Odessa: TES. (in Russian) 


\section{ЕКОЛОГІЯ НА ТРАНСПОРТІ}

3. Gerasimov, G. N. (2001). Protsessy koagulyautsii-flokulyatsii pri obrabotke poverkhnostnykh vod. Vodosnabzheniye i sanitarnaya tekhnika, 3, 26-31. (in Russian)

4. Draginskiy, V. L., Alekseeva, L. P., \& Getmantsev, S. V. (2005). Koagulyatsiya v tekhnologii ochistki prirodnikh vod. Moskow: Nauka. (in Russian)

5. Zhurba, M. G., Sokolov, L. I., \& Govorova, Z. M. (2010). Vodosnabzhenie. Proektirovanie sistem i sooruzheniy, v 3t. T2. Ochistka i konditsionirovanie prirodnykh vod. Izd. 3-e, pererab. i dop.: Uchebnoe posobie. Moskow: ASV. (In Russian)

6. Zapolskiy, A. K. (2005). Vodopostachannya, vodovidvedennya ta yakist vodi: Pidruchnik. Kyiv: Vyshcha shkola. (In Ukranian)

7. Myakishev, V. A. (2005). Modernizatsiya kommunalnykh sistem vodosnabzheniya i vodootvedeniya. Simferopol: NAPKS. (IN Russian)

8. Oleynik, O. Y., \& Kaydalov, V. Y. (2014). Ispolzovanie polimerbetona dlya stroitelstva smotrovykh shakht sistem vodootvedeniya. Komunalne hospodarstvo mist: naukovo-tekhnichnyi zbirnyk Kharkivskoho natsionalnoho universytetu miskoho hospodarstva imeni O. M. Beketova, 114, 18-21. (In Russian)

9. Epoyan, S. M., Blagodarnaya, G. I., Dushkin, S. S., \& Stashuk V. A. (2013). Povyshenie effektivnosti raboty sooruzheniy pri ochistke pitevoy vody: Monografiya. Kharkiv: KhNAGKh. (In Russian)

10. Vasylenko, O. A., Hrabovskyi, P. O., \& Larkina, H. M. at al. (2010). Rekonstruktsiia i intensyfikatsiia sporud vodopostachannia ta vodovidvedennia: Navchalnyi posibnyk. Kharkiv: Ukrheliotekh. (In Russian)

11. Rybev, I. A. (2002). Stroitelnoe materialovedenie: Uchebnoe posobie dlya VUZov. Moskow: Vyshcha shkola. (In Russian)

12. Kulikov, N. I., Naymanov, A. Y., Omelchenko, N. P., \& Chernyshev, V. N. (2009). Teoreticheskie osnovy ochistki vody: Uchebnoe posobie. Donetsk: Noulidzh. (In Russian)

13. Tuhai, A. M., \& Orlov, V. O. (2009). Vodopostachannia: Pidruchnyk. Kyiv: Znannia. (In Ukranian)

14. Khoruzhyi, P. D., Khomutetska, T. P., \& Khoruzhyi, V. P. (2008). Resursozberihaiuchi tekhnolohii vodopostachannia. Kyiv: Ahrarna nauka. (In Ukranian)

15. Shevchenko, V. A. (2012). Tekhnologiya i primenenie spetsialnikh betonov: Uchebnoe posobie. Krasnoyarsk: SFU. (In Russian)

16. Epoyan, S. M., Sukhorukov, G. I., \& Yarkin, V. A. (2016). Metod povysheniya effektivnosti smeshcheniya prirodnoy vody i metodika provedeniya issledovaniy. Naukoviy visnik budivnitstva, 1(83), 187-193. (In Russian)

17. Biliaiev, M. M., \& Kozachyna, V. A. (2015). Numerical determination of horizontal settlers performance. Science and Transport Progress, 4(58), 34-43. doi: 10.15802/stp2015/49201. (in English)

18. Bratby, J. (2016). Coagulation and Floculation in Water and Wastewater Treatment. Third Ed. London: IWA Publishing. (In English)

19. Kozachyna, V. A. (2016). Investigation of admixture sedimentation in the horizontal settler. Science and Transport Progress, 4(64), 7-14. (In English)

20. Pontius, F. W. (2016). Chitosan as a Drinking Water Treatment Coagulant. American Journal of Civil Engineering, 4(5), 205-215. doi: 10.11648/j.ajce.20160405.11. (In English)

Prof. M. M. Biliaiev, Dr. Sc. (Tech.) (Ukraine) recommended this article to be published

Received: Oct. 10, 2017

Accessed: Jan. 11, 2018 